\title{
Genetic Characterization of Pathogenic Leptospira Species by DNA Hybridization
}

\author{
P. RAMADASS, ${ }^{1}$ B. D. W. JARVIS,${ }^{2}$ R. J. CORNER, ${ }^{1}$ D. PENNY, ${ }^{2}$ AND R. B. MARSHALL ${ }^{1 *}$ \\ Department of Veterinary Pathology and Public Health, Faculty of Veterinary Science, ${ }^{1}$ and Department of \\ Microbiology and Genetics, ${ }^{2}$ Massey University, Palmerston North, New Zealand
}

\begin{abstract}
A total of 66 serovars of potentially pathogenic Leptospira species were examined by slot blot hybridization, and 57 of these serovars were classified in six DNA homology groups. In cases in which common serovars were studied, the results were in general agreement with the results of previous workers, who used different DNA homology methods. However, we propose a new species, Leptospira kirschneri, comprising the following serovars: bulgarica, butembo, cynopteri, dania, grippotyphosa, kabura, kambale, ramisi, and tsaratsovo. Seven of these serovars have not had their DNAs studied by other workers.
\end{abstract}

Differentiation of strains within Leptospira species based upon variations in antigenic composition was introduced nearly 40 years ago. A total of 223 Leptospira serovars have been identified, and for convenience these serovars are grouped into 23 serogroups (10).

Haapala et al. in 1969 (5) and Brendle et al. in 1974 (1) reported DNA base compositions of and measured levels of DNA homology between selected leptospire strains. The methods which these authors used had the potential to indicate the genetic structure of the genus Leptospira and to provide information that could be used to produce a phylogenetic classification. The results of a comprehensive study of 45 serovars in which quantitative DNA-DNA hybridization experiments were performed were published in 1987 (17). A total of 40 pathogenic strains were placed in five homology groups and were described as new species of the genus Leptospira. Leptospira interrogans was restricted to serovars icterohaemorrhagiae, copenhageni, canicola, pomona, saxkoebing, wolff, pyrogenes, autumnalis, bataviae, jalna, australis, smithi, schueffneri, zanoni, grippotyphosa, djasiman, and hebdomadis; Leptospira noguchi comprised serovars panama, fortbragg, and louisiana; Leptospira weilii comprised serovars celledoni and sarmin; Leptospira santarosai comprised serovars shermani, borincana, peru, hawaiin, bananal, atlantae, bakeri, and navet; Leptospira borgpetersenii comprised serovars javanica, ballum, mini, tarassovi, and sejroe; and Leptospira inadai comprised serovar lyme. Yasuda et al. (17) determined levels of relatedness at 55 and $70^{\circ} \mathrm{C}$ by using the hydroxyapatite method (2). In this study we found that it was impractical to obtain the quantities of leptospire DNA that are required by this method for an extensive survey and instead used slot blot hybridization at $60^{\circ} \mathrm{C}$. We found that the results obtained with slot blot hybridization were accurate and reproducible. Our results are in good agreement with those of Yasuda et al. (17).

In this paper we describe the use of a quantitative slot blot hybridization method to determine the levels of DNA relatedness of 66 pathogenic leptospire serovars; to do this, we used 16 strains as sources of labeled reference DNA.

\footnotetext{
* Corresponding author.
}

\section{MATERIALS AND METHODS}

Leptospira serovars and culture conditions. Cultures of Leptospira strains were obtained either from the WHO/FAO Collaborating Leptospirosis Laboratory, Brisbane, Australia, or from field isolates that were cultured in the Leptospirosis Laboratory, Department of Veterinary Pathology and Public Health, Massey University, Palmerston North, New Zealand. The reference strains used in this study are listed in Table 1 . A restriction enzyme analysis was carried out (14) for each strain to ensure that it provided a unique restriction enzyme pattern, and the identity of each strain was verified by comparing its pattern with previously published patterns if these were available. Agglutination tests were used to identify strains with known antisera. Organisms were cultured in EMJH medium (9) for 5 to 7 days at $30^{\circ} \mathrm{C}$.

Preparation of DNA. Leptospira DNAs were prepared from 1-liter cultures in EMJH medium by using the method of Marshall et al. (14). The DNA intended for probe production was purified by cesium chloride density gradient centrifugation (13). This step was omitted when DNA that was to be probed was prepared.

Slot blot hybridization. Slot blot hybridization was performed by using the method of Kafatos et al. (11), with some modifications. Aqueous DNA solutions $(0.5 \mu \mathrm{g}$ in $10 \mu \mathrm{l})$ were denatured with $100 \mu \mathrm{l}$ of a $0.4 \mathrm{M}$ sodium hydroxide solution for $10 \mathrm{~min}$ at room temperature, neutralized with $100 \mu \mathrm{l}$ of a $2.0 \mathrm{M}$ ammonium acetate solution, and transferred to a nitrocellulose membrane type (BA85; Schleicher and Schuell, Inc., Dassel, Germany) in a slot blot apparatus (Bio-Rad) under a vacuum. After $45 \mathrm{~min}$, the samples were washed twice with $2 \times \mathrm{SSC}(1 \times \mathrm{SSC}$ is $0.15 \mathrm{M}$ sodium chloride plus $0.015 \mathrm{M}$ trisodium citrate). The nitrocellulose membrane filter was placed in a vacuum oven at $80^{\circ} \mathrm{C}$ for $2 \mathrm{~h}$. The membrane was placed in a heat-sealed plastic bag with $10 \mathrm{ml}$ of hybridization buffer (6) and prehybridized at $60^{\circ} \mathrm{C}$ in a water bath for $2 \mathrm{~h}$. Radioactive probes were prepared from sonicated genomic DNA ( $3 \mu \mathrm{g})$ by using the random primer method (16) (average specific activity, $1.7 \times 10^{6} \mathrm{cpm} / \mu \mathrm{g}$ ), heat denatured, cooled in ice, and added $\left(1 \times 10^{6}\right.$ to $1.5 \times$ $10^{6} \mathrm{cpm}$ ) to the prehybridized membrane in hybridization buffer, and the preparation was incubated for 18 to $24 \mathrm{~h}$ at $60^{\circ} \mathrm{C}$. The membrane was washed twice for $15 \mathrm{~min}$ in $2 \times$ $\mathrm{SSC}$, once for $15 \mathrm{~min}$ in $0.1 \times \mathrm{SSC}$ at room temperature, and once for $15 \mathrm{~min}$ in $0.1 \times \mathrm{SSC}$ at $50^{\circ} \mathrm{C}$; then it was dried at room temperature, wrapped in plastic cling wrap, and ex- 
TABLE 1. Reference strains used in this study ${ }^{a}$

\begin{tabular}{|c|c|c|c|c|c|}
\hline Strain no. & Serovar & Strain & Strain no. & Serovar & Strain \\
\hline 1 & hardjo & Hardjoprajitno & 34 & moldaviae & $114-2$ \\
\hline 2 & canicola & Hond Utrecht IV & 35 & atchafalaya & LSU 1013 \\
\hline 3 & australis & Ballico & 36 & poi & Poi \\
\hline 4 & pomona & Pomona & 37 & kennewicki & LT 1026 \\
\hline 5 & copenhageni & M 20 & 38 & haemolytica & Marsh \\
\hline 6 & bratislava & Jez-Bratislava & 39 & ricardi & Richardson \\
\hline 7 & bataviae & Swart & 40 & kambale & Kambale \\
\hline 8 & ballum & Mus 127 & 41 & vietnam & DRV \\
\hline 9 & balcanica & T78 (New Zealand field isolate) & 42 & atlantae & LT 81 \\
\hline 10 & javanica & Veldrat Batavia 46 & 43 & kisuba & Kisuba \\
\hline 11 & hardjobovis & 08/2 (New Zealand field isolate) & 44 & sumatrana & Sapulette \\
\hline 12 & cynopteri & $3522 \mathrm{C}$ & 45 & georgia & LT 117 \\
\hline 13 & grippotyphosa & Moskva V & 46 & $\operatorname{mini}$ & Sari \\
\hline 14 & cellodoni & Cellodoni & 47 & guidae & RP 29 \\
\hline 15 & shermani & $1342 \mathrm{~K}$ & 48 & saxkoebing & M 84 \\
\hline 16 & fortbragg & Fort Bragg & 49 & icterohaemorrhagiae & RGA \\
\hline 17 & wolffi & 3705 & 50 & cornelli & $\mathrm{CB}$ \\
\hline 18 & pyogenes & Salinem & 51 & ramisi & Musa \\
\hline 19 & tarassovi & Perepelicyn & 52 & dania & K1 \\
\hline 20 & hebdomadis & Hebdomadis & 53 & peruviana & V 42 \\
\hline 21 & jalna & Jalna & 54 & muenchen & Muenchen C9 \\
\hline 22 & louisiana & LSU 1945 & 55 & bangkok & Bangkok D92 \\
\hline 23 & djasiman & Djasiman & 56 & fugis & Fudge \\
\hline 24 & bakeri & LT 79 & 57 & monjakov & Monjakov \\
\hline 25 & autumnalis & Akiyami A & 58 & nicaragua & 1011 \\
\hline 26 & kabura & Kabura & 59 & tropica & CZ 299 \\
\hline 27 & bravo & Bravo & 60 & tunis & P $2 / 65$ \\
\hline 28 & tsaratsovo & $\mathrm{B} 81 / 7$ & 61 & rama & 316 \\
\hline 29 & butembo & Butembo & 62 & bulgarica & Nikolaevo \\
\hline 30 & lora & Lora & 63 & swajizak & Swajizak \\
\hline 31 & worsfoldi & Worsfold & 64 & gatuni & $1473 \mathrm{~K}$ \\
\hline 32 & kremastos & Kremastos & 65 & borincana & HS 622 \\
\hline 33 & medanensis & Hond HC & 66 & luis & M 6 \\
\hline
\end{tabular}

${ }^{a}$ All of the strains except strains T78 and 08/2 were obtained from the WHO/FAO Collaborating Leptospirosis Laboratory, Brisbane, Australia; strains T78 and $08 / 2$ were field isolates that were cultured in the Leptospirosis Laboratory, Department of Veterinary Pathology and Public Health, Massey University.

posed overnight to X-ray film (Agfa-Gevaert Curix RP2) at $-70^{\circ} \mathrm{C}$ by using an intensifying screen (Dupont Cronex Lightning Plus). The autoradiogram was developed in a Kodak automatic film processor. Each membrane carried a known positive DNA (homologous unlabeled DNA), a negative DNA (Escherichia coli DNA), and several test DNAs. Each DNA was tested in duplicate.

A quantitative estimate of the level of DNA homology was obtained by cutting individual slots from the membrane and counting the associated radioactivity with a liquid scintillation counter (15). The percentage of homology was calculated by dividing the counts per minute obtained with heterologous DNA by the counts per minute obtained with homologous DNA and multiplying by 100 .

Phylogenetic relationships. Relationships between serovars were determined by using the distance matrix program KITSCH (J. Felsenstein, University of Washington). The homology values in Table 2 were converted into taxonomic distances by subtracting them from 100 . The program used the method of Fitch and Margoliash (4) for fitting trees to distance matrices and examined all possible trees to find one which minimized the sum of the squared distances between taxa. This tree was printed out with a table showing taxonomic distances between points on it. Figure 1 was drawn to scale from the taxonomic distance data.

Phenotypic characteristics. The strains which we studied were tested for their ability to grow at incubation temperatures of 13,29 , and $37^{\circ} \mathrm{C}$. They were also tested for their ability to grow in the presence of 8 -azaguanine $(225 \mu \mathrm{g} / \mathrm{ml})$ (10) and 2,6-diaminopurine $(10 \mu \mathrm{g} / \mathrm{ml})$. Each strain was tested in duplicate in EMJH medium by using essentially the method of Johnson and Faine (8) and Johnson and Harris (9). Growth was measured by visually inspecting the preparations at 7-day intervals for a period of 28 days. The viability of strains which did not appear to grow was verified by subculturing them into EMJH medium and incubating the subcultures at $29^{\circ} \mathrm{C}$.

\section{RESULTS}

DNA relatedness of serovars. A total of 16 radioactive reference DNAs were prepared by using DNAs from the following serovars: australis, balcanica, ballum, bataviae, bratislava, canicola, copenhageni, celledoni, cynopteri, fortbragg, grippotyphosa, hardjo, hardjobovis, javanica, pomona, and shermani. These reference DNAs were hybridized with DNAs from 66 serovars. The percentage of homology for each combination tested is shown in Table 2. The KITSCH program was used to draw a phylogenetic tree (Fig. $1)$, which showed the relationships among the first 16 serovars for which an almost complete set of reciprocal data was available. In the small number of cases in which only one value was available, the reciprocal value was assumed to be equal to the first value. For example, the level of relatedness between reference DNA from strain 3 (serovar australis) and DNA from strain 6 (serovar bratislava) was assumed to be 
TABLE 2. Levels of DNA-DNA relatedness, as determined by slot blot hybridization at $60^{\circ} \mathrm{C}$, for 16 strains of reference serovars and 66 strains of other serovars of potentially pathogenic leptospires

\begin{tabular}{|c|c|c|c|c|c|c|c|c|c|c|c|c|c|c|c|c|c|}
\hline \multicolumn{2}{|c|}{ Unlabeled DNA from: } & \multicolumn{16}{|c|}{$\%$ Relatedness with labeled DNA from strain: } \\
\hline Strain $^{a}$ & Serovar & 1 & 2 & 3 & 4 & 5 & 6 & 7 & 8 & 9 & 10 & 11 & 12 & 13 & 14 & 15 & 16 \\
\hline 1 & hardjo & 100 & 68.7 & 78.8 & 67.4 & 80.9 & 77.6 & 75.3 & 7.4 & 2.8 & 3.1 & 2.8 & 9.5 & 21.9 & 2.6 & 2.7 & 14.2 \\
\hline 2 & canicola & 100 & 100 & 59.8 & 89.8 & 72.5 & 100 & 74.4 & 9.7 & 3.5 & 13.0 & & 5.7 & 31.6 & 4.7 & 1.5 & 12.8 \\
\hline 3 & australis & 99.3 & 79.9 & 100 & 67.5 & 77.8 & 100 & 60.9 & 7.1 & 5.4 & 4.2 & & 7.3 & 26.2 & 6.2 & 2.4 & 12.5 \\
\hline 4 & pomona & 88.6 & 69.0 & 75.1 & 100 & 78.5 & 100 & 97.8 & 7.8 & 4.0 & 6.8 & & 8.1 & 29.5 & 2.5 & 2.5 & 20.0 \\
\hline 5 & copenhageni & 86.3 & 62.4 & 72.1 & 57.0 & 100 & 100 & 85.9 & 7.7 & 3.3 & 5.0 & 3.5 & 5.7 & 32.9 & 2.3 & 2.9 & 17.8 \\
\hline 6 & bratislava & 79.7 & 82.2 & & & 95.9 & 100 & & 4.5 & & & 2.1 & 27.2 & & 1.1 & 3.7 & 14.2 \\
\hline 7 & bataviae & 100 & 97.6 & 76.6 & 88.1 & 98.2 & 100 & 100 & 12.8 & 1.4 & 7.5 & & 37.5 & 18.0 & 4.5 & 5.2 & 12.3 \\
\hline 8 & ballum & 5.6 & 3.4 & 4.0 & 0 & 0 & 0 & 0.8 & 100 & 55.7 & 38.1 & 36.3 & 0.7 & 1.7 & 12.0 & 3.7 & 2.2 \\
\hline 9 & balcanica & 5.3 & 3.3 & 5.7 & 1.7 & 2.4 & 1.9 & 3.1 & 69.5 & 100 & 100 & 100 & 1.5 & 6.1 & 19.3 & 12.9 & 4.0 \\
\hline 10 & javanica & 5.2 & 7.5 & 4.5 & 3.7 & 6.9 & 2.1 & 4.1 & 91.2 & 76.0 & 100 & 34.8 & 2.5 & 3.8 & 11.3 & 8.7 & 2.6 \\
\hline 11 & hardjobovis & 8.1 & 8.1 & & & 7.7 & & & 100 & 90.2 & & 100 & 13.3 & & & 36.9 & 5.0 \\
\hline 12 & cynopteri & 28.5 & 34.7 & 28.6 & 23.4 & 23.6 & 49.1 & 27.9 & 7.5 & 4.5 & 3.7 & 2.9 & 100 & 88.0 & 4.2 & 1.6 & 14.1 \\
\hline 13 & grippotyphosa & 34.9 & 44.4 & 28.9 & 15.7 & 39.2 & & 36.2 & 21.1 & 5.3 & 10.1 & 3.7 & 100 & 100 & 4.9 & 4.9 & 19.5 \\
\hline 14 & celledoni & 4.0 & 4.5 & 6.3 & 1.1 & 2.8 & 0.2 & 4.0 & 21.4 & 21.9 & 41.4 & 16.2 & 0.5 & 4.3 & 100 & 12.3 & 2.9 \\
\hline 15 & shermani & 6.7 & 8.7 & 3.7 & 2.5 & 3.8 & 4.6 & 4.2 & 21.9 & 9.3 & 42.8 & 13.4 & 2.9 & 3.3 & 6.9 & 100 & 1.8 \\
\hline 16 & fortbragg & 14.4 & 26.2 & 8.7 & 16.2 & 20.8 & 40.3 & 26.3 & 3.5 & 5.7 & 7.8 & 5.1 & 27.7 & 21.8 & 0 & 3.1 & 100 \\
\hline 17 & wolffi & 78.4 & 87.7 & 80.2 & 46.1 & 87.0 & 76.0 & 72.8 & 13.9 & 2.5 & 6.9 & & 26.1 & 20.8 & 7.4 & 1.0 & 15.5 \\
\hline 18 & pyogenes & 100 & 93.8 & 81.9 & 83.9 & 86.6 & 67.9 & 82.6 & 12.3 & 3.3 & & & 25.8 & 31.8 & 4.2 & 3.0 & 10.4 \\
\hline 19 & tarassovi & 8.1 & 11.4 & 5.0 & 3.5 & 6.0 & 2.8 & 4.6 & 100 & 100 & 100 & 88.7 & 6.4 & 5.4 & 17.5 & 12.2 & 5.4 \\
\hline 20 & hebdomadis & 60.1 & 81.8 & 100 & 100 & 72.9 & 53.1 & 60.4 & 15.4 & 5.1 & 6.1 & & 18.3 & 14.6 & 3.4 & 4.9 & \\
\hline 21 & jalna & 89.2 & 100 & 78.7 & 94.8 & 100 & & & 3.1 & 6.2 & 13.8 & & 42.8 & 44.8 & 0 & 6.4 & \\
\hline 22 & louisiana & 22.0 & 29.4 & 17.9 & 9.0 & 22.4 & 27.5 & & 4.4 & 4.2 & 10.2 & & 33.3 & 34.2 & 0 & 7.1 & 81.7 \\
\hline 23 & djasiman & 84.8 & 100 & 68.2 & 100 & 97.0 & 100 & & 23.3 & 4.3 & & & 28.3 & & 5.0 & 4.4 & 14.3 \\
\hline 24 & bakeri & 8.0 & 10.3 & 4.6 & 2.8 & 12.9 & 4.8 & 5.7 & 30.7 & 11.5 & 25.0 & 7.8 & 6.9 & 3.9 & 8.7 & 90.0 & 4.5 \\
\hline 25 & autumnalis & 76.6 & 84.0 & & 77.5 & 100 & 100 & & 2.2 & 0 & 7.2 & & 27.1 & 15.5 & & 3.5 & \\
\hline 26 & kabura & 36.9 & 26.0 & & 33.4 & 40.7 & 46.9 & & 5.8 & 1.4 & & & 78.3 & 75.3 & 3.9 & 1.8 & 17.5 \\
\hline 27 & bravo & 6.8 & 1.7 & & & 3.2 & 4.3 & & 12.2 & 7.8 & & & 5.8 & & 9.1 & 56.2 & 2.3 \\
\hline 28 & tsaratsovo & 37.6 & 17.0 & & & 38.9 & 24.7 & & 6.1 & 0.8 & & & 85.1 & 49.4 & 3.2 & 0 & 17.2 \\
\hline 29 & butembo & 19.2 & 14.9 & & & 32.1 & 29.6 & & 5.5 & 0.6 & & & 88.5 & 57.5 & 2.5 & 1.6 & 13.9 \\
\hline 30 & lora & 96.8 & 88.0 & & & 100 & 100 & & 5.3 & 2.4 & & & 43.5 & & 9.3 & 1.8 & 19.0 \\
\hline 31 & worsfoldi & 8.2 & 4.4 & & & 9.1 & 3.3 & & 45.8 & 17.6 & & & 4.1 & & 97.5 & 13.4 & 0.8 \\
\hline 32 & kremastos & 96.6 & 94.8 & & & 100 & 100 & & 8.0 & 7.6 & & & 37.4 & & 12.5 & 5.6 & 16.6 \\
\hline 33 & medanensis & 100 & 100 & & & 100 & 100 & & 6.6 & 5.4 & & & & & 9.3 & 5.3 & 19.6 \\
\hline 34 & moldaviae & 5.5 & 5.7 & & & 8.3 & 3.0 & & 100 & 100 & & 71.1 & 6.2 & & 31.4 & 10.3 & 3.6 \\
\hline 35 & atchafalaya & 3.2 & 4.2 & & & 4.4 & 2.2 & & 13.3 & & & & 3.4 & & 3.9 & 41.8 & 4.2 \\
\hline 36 & poi & 6.7 & 4.4 & & & 7.0 & 3.9 & & 95.7 & 62.0 & & 31.7 & 5.2 & & 18.8 & 3.5 & 3.4 \\
\hline 37 & kennewicki & 60.4 & 100 & & & 100 & 86.6 & & 5.9 & & & & 36.9 & & 1.3 & 1.9 & 21.0 \\
\hline 38 & haemolytica & 61.3 & 100 & & & 100 & 90.8 & & 5.2 & & & & 27.0 & & 5.1 & 4.5 & 12.3 \\
\hline 39 & ricardi & 50.8 & 79.0 & & & 100 & 93.4 & & 3.6 & & & & 23.7 & & 1.1 & 3.7 & 16.5 \\
\hline 40 & kambale & 24.4 & 29.5 & & & 27.3 & 30.2 & & 7.9 & & & & 88.8 & 51.0 & 2.6 & 4.5 & 19.2 \\
\hline 41 & vietnam & 9.3 & 6.7 & & & 6.9 & 2.5 & & 100 & 73.7 & & 75.4 & 4.3 & & 13.8 & 10.5 & 4.4 \\
\hline 42 & atlantae & 100 & 78.2 & & & 100 & & & 8.2 & & & & 14.3 & & 7.6 & 4.9 & 10.2 \\
\hline 43 & kisuba & 3.6 & 2.7 & & & 2.6 & & & 100 & 79.3 & & 46.7 & 3.0 & & 18.9 & 16.7 & 2.2 \\
\hline 44 & sumatrana & 100 & 100 & & & 91.7 & & & 8.8 & & & & 20.4 & & 5.3 & 1.0 & 15.6 \\
\hline 45 & georgia & 3.2 & 2.7 & & & 2.2 & & & 20.7 & & & & 2.4 & & 10.0 & 73.4 & 2.8 \\
\hline 46 & $\operatorname{mini}$ & 3.1 & 2.3 & & & 3.1 & & & 100 & 76.4 & & 35.6 & 2.9 & & 17.8 & 5.3 & 1.3 \\
\hline 47 & guidae & 5.9 & 5.9 & & & 7.3 & & & 100 & 78.1 & & 90.1 & 5.0 & & 13.9 & 10.7 & 5.0 \\
\hline 48 & saxkoebing & 6.6 & 7.3 & & & 10.3 & & & 100 & 72.7 & & 37.4 & 8.6 & & 15.0 & 8.4 & 3.9 \\
\hline 49 & ictero & 100 & 100 & & 100 & 100 & & & 8.4 & & & 2.8 & 14.7 & & & & 12.1 \\
\hline 50 & cornelli & & 62.5 & & 61.8 & 79.8 & & & 0.2 & 1.1 & & 2.0 & 23.8 & & 1.5 & 1.9 & 13.2 \\
\hline 51 & ramisi & 17.2 & 31.3 & & & 38.1 & & & 1.3 & 3.8 & & 3.7 & 76.8 & 45.8 & 2.3 & 0.3 & 29.7 \\
\hline 52 & dania & 14.7 & 20.5 & & & 33.9 & & & 3.3 & 1.6 & & 3.0 & 83.4 & & 2.5 & 0 & 19.6 \\
\hline 53 & peruviana & 19.3 & 29.3 & & & 39.9 & & & 8.0 & 4.7 & & 3.5 & 28.5 & & 2.4 & 0 & 89.7 \\
\hline 54 & muenchen & 18.8 & 21.3 & & & 34.7 & & & 8.2 & 5.2 & & & 21.7 & & 1.8 & 1.1 & 86.1 \\
\hline 55 & bangkok & 77.9 & 100 & & & 100 & & & 5.5 & 3.5 & & & 22.5 & & 5.4 & 1.7 & 23.9 \\
\hline 56 & fugis & 49.0 & 44.2 & & & 88.7 & & & 2.4 & 3.6 & & & 14.8 & & 3.8 & 0 & 16.3 \\
\hline 57 & monjakov & 72.7 & 63.5 & & & 71.1 & & & 2.8 & 2.0 & & & 13.4 & & 1.9 & 0 & 17.2 \\
\hline 58 & nicaragua & 22.1 & 31.0 & & & 62.2 & & & 4.1 & 4.1 & & & 26.0 & & 2.9 & 3.2 & 100 \\
\hline 59 & tropica & 1.4 & 0.6 & & & 5.6 & 4.7 & & 15.1 & 6.3 & & & 0.9 & & 9.1 & 81.3 & 2.0 \\
\hline 60 & tunis & 4.9 & 2.8 & & & 5.1 & 0 & & 18.3 & 7.6 & & & 2.0 & & 11.7 & 93.8 & 2.8 \\
\hline 61 & rama & 1.1 & 0.7 & & & 6.7 & & & 16.6 & 6.6 & & & 2.6 & & 7.7 & 26.6 & 4.3 \\
\hline 62 & bulgarica & 23.5 & 35.8 & & & 59.0 & & & 3.9 & 3.3 & & & 100 & & 2.2 & 1.1 & 27.3 \\
\hline 63 & swajizak & 25.5 & & & 3.0 & 4.3 & & & 1.8 & 4.2 & & & 11.5 & 9.8 & 2.6 & & 13.4 \\
\hline 64 & gatuni & 8.9 & 5.9 & & & 6.4 & 4.5 & & 13.6 & & & & 1.7 & & 7.9 & 19.8 & 3.1 \\
\hline 65 & borincana & 1.3 & 1.9 & & & 7.1 & & & 7.7 & 6.9 & & & 0.6 & & 3.6 & 28.7 & 0 \\
\hline 66 & luis & 1.4 & 0.7 & & & 8.3 & & & 14.2 & 6.2 & & 7.5 & 3.4 & & 4.1 & 56.6 & 4.1 \\
\hline
\end{tabular}




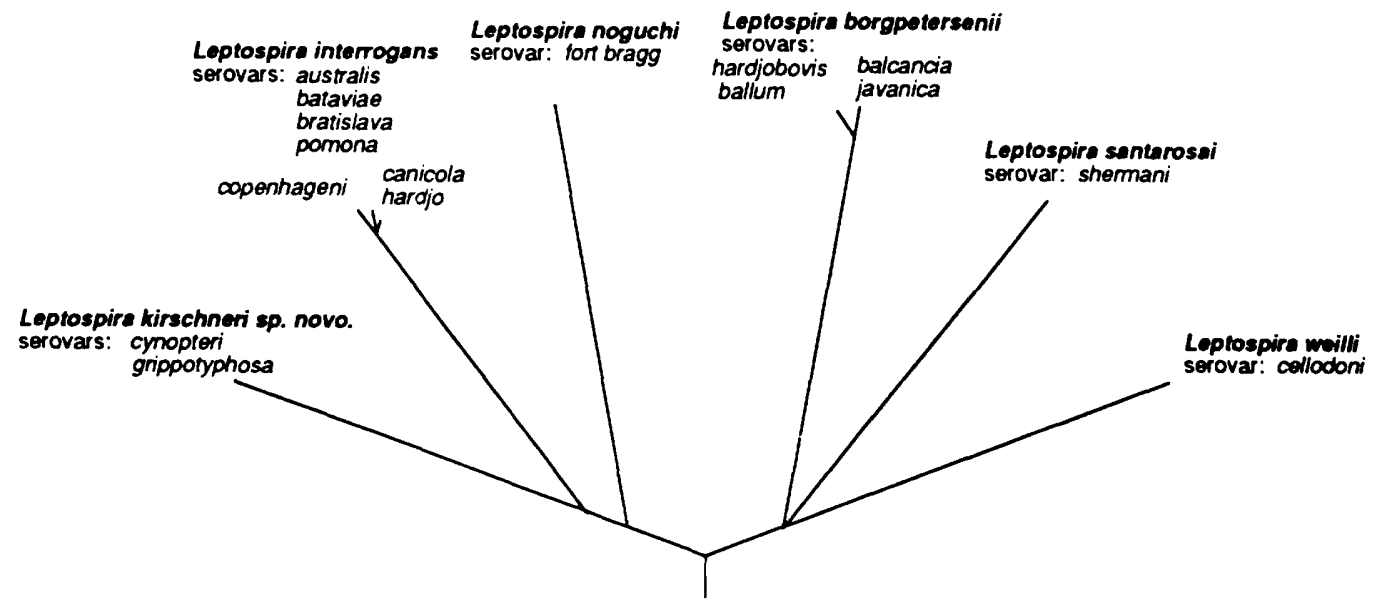

FIG. 1. Phylogentic tree generated by the $\mathrm{KITSCH}$ computer program, showing the relationships among 16 serovars of Leptospira species. The lengths of the branches are proportional to the time of evolution.

the same as the level of relatedness between reference DNA from strain 6 (serovar bratislava) and DNA from strain 3 (serovar australis). In the few cases in which both values were missing for a pair of serovars and the groups to which these serovars belonged showed little relationship, the average level of relationship between members of the two groups was used as the level of relationship between the pair of serovars. For instance, the mean level of relatedness between $L$. interrogans (strains 1 to 7 ) and L. borgpetersenii (strains 8 to 11 ) in Fig. 1 was $4.8 \%$ (range, 0 to $13.0 \%$ ). The mean was used when the level of intergroup relatedness for particular strain pairs (strains 3 and 11, 4 and 11, and 7 and 11) was not available from Table 2. Figure 1 shows the phylogenetic tree drawn to scale from the taxonomic distance data. The program which we used assumes that all tip species are contemporaneous and that there is an evolutionary clock. Consequently, the total length from the root to each serovar is the same, and the distances between serovars and their common origin are proportional to lengths of time that they have been evolving separately.

If strains could not be grouped by the KITSCH program because reciprocal data were not available, they were considered to be related if they exhibited at least $60 \%$ relatedness with one or more reference strains (7). Strains which exhibited more than $60 \%$ relatedness with one reference strain and less than $60 \%$ relatedness with another reference strain belonging to the same relatedness group were left unclassified (for example, serovars fugis and nicaragua in $L$. interrogans [strains 56, 58, and 8 in Table 2]).

When genospecies were defined in this way, L. interrogans, L. borgpetersenii, Leptospira kirschneri, L. santarosai, L. noguchi, and $L$. weilii contained $25,12,9,5,4$, and 2 strains, respectively, and the mean levels of within-species relatedness were $85.6,78,76.3,84.6,85.8$, and $98.8 \%$, respectively. These six genospecies could be divided into two groups corresponding to those shown in Fig. 1. $L$. interrogans, L. kirschneri, and $L$. noguchi were the members of one group, and L. borgpetersenii, L. santarosai, and $L$. weilii were the members of the other group (with a mean level of interspecies relatedness of $14.2 \%$ ). The mean level of relatedness between species belonging to different groups was $3.6 \%$. Nine serovars could not be grouped with the reference DNAs which we used; these unclassified serovars were serovars atchafalaya, ballum, borincana, bravo, gatuni, luis, nicaragua, rama, and szwajizak. The relationships between serovars and genospecies are as follows: $L$. interrogans, serovars atlantae, australis, autumnalis, bangkok, bataviae, bratislava, canicola, copenhageni, cornelli, djasiman, fugis, hardjo, hebdomadis, haemolytica, icterohaemorrhagiae, jalna, kennewicki, kremastos, lora, medanensis, monjakov, pomona, pyogenes, ricardi, sumatrana, and wolfii; L. borgpetersenii, serovars balcanica, guidae, hardjobovis, javanica, kisuba, mini, moldaviae, poi, saxkoeburg, tarassovi, and vietnam; L. kirschneri sp. nov., serovars bulgarica, butembo, cynopteri, dania, grippotyphosa, kabura, kambale, ramisi, and tsaratsovo; L. noguchi, serovars fort bragg, louisiana, muenchen, and peruviana; $L$. santarosai, serovars bakeri, georgia, shermani, tropica, and tunis; and $L$. weilii, serovars celledoni and worsfoldi.

Phenotypic relationships between serovars. The responses of the serovars to different incubation temperatures were also studied. Growth was barely discernable after 14 days at $13^{\circ} \mathrm{C}$, but all serovars remained viable throughout this incubation period. At $37^{\circ} \mathrm{C}$ some strains died within 1 month, and in most cases they reached maximum turbidity after either 7 or 14 days. All strains grew at $29^{\circ} \mathrm{C}$ and remained viable for 1 month. All serovars were inhibited by 8 -azaguanine, and the response to 2,6-diaminopurine was variable; 32 strains grew in the presence of this purine, and 12 were being inhibited. No particular pattern was observed. Of the seven serovars which we classified as belonging to L. kirschneri, only one (serovar dania) grew in the presence of 2,6diaminopurine.

\section{DISCUSSION}

DNA relatedness. Figure 1 shows that the pathogenic serovars which we examined fell into two clearly defined groups; one of these groups contained $L$. interrogans, $L$. noguchi, and L. kirschneri sp. nov., and the other group contained $L$. borgpetersenii, $L$. santarosai, and $L$. weilii. This suggests that two ancestral strains diverged and then contemporary species evolved from them over a longer time. Members of the same genospecies are closely related and are separated by small distances or are not separated at all in Fig. 1. Our results are in general agreement with those of previous workers $(1,5,17)$. However, there are a few differences. Haapala et al. (5) placed serovars bataviae, 
pomona, and australis in one group, and we agree. However, the other group of these authors consisted of serovars javanica, celledoni, and hyos (tarassovi), but we found that serovars javanica and tarassovi belong to L. borgpetersenii, while serovar celledoni belongs to $L$. weilii. The difference may be due to the different hybridization methods used.

Brendle et al. (1) grouped serovars bataviae, muenchen, icterohaemorrhagiae, and kabura together. In our study, serovar muenchen DNA exhibited a high level of homology with serovar fortbragg DNA and was therefore considered a serovar of $L$. noguchi. Serovars bataviae and icterohaemorrhagiae were classified as $L$. interrogans, and serovar kabura DNA exhibited 75 and $78 \%$ relatedness with serovar grippotyphosa and cynopteri reference DNAs, respectively, and was classified as a serovar of $L$. kirschneri.

Our results agree with those of Yasuda et al. (17) except for two serovars, serovars atlantae and grippotyphosa. Serovar atlantae DNA exhibited 100 and $78.2 \%$ relatedness with reference DNAs from serovars hardjo and canicola, respectively, and was classified as a serovar of $L$. interrogans. Yasuda et al. (17) included serovar atlantae as a serovar of $L$. santarosai. This discrepancy was not pursued. Our results also indicated that serovar grippotyphosa should be considered a serovar of $L$. kirschneri, but Yasuda et al. (17) described serovar grippotyphosa as a serovar of $L$. interrogans. In the study of these authors serovar grippotyphosa DNA exhibited $100 \%$ relatedness with serovar copenhageni reference DNA, but our results indicated that serovar grippotyphosa DNA was only $33 \%$ related to serovar copenhageni reference DNA. To further confirm our initial serovar grippotyphosa hybridization results, another culture of this organism was obtained from the Centers for Disease Control, Atlanta, Ga. The DNA from this new culture confirmed the results of our initial tests. We consider serovar grippotyphosa to be a serovar of $L$. kirschneri rather than a serovar of $L$. interrogans.

The homology values are not sufficiently clear-cut to decide to which group serovars fugis, nicaragua, and ballum belong. These and other ungrouped leptospires will require further study in which a larger number of reference DNAs are used.

Phenotypic characteristics. The characteristics which we determined in this study allowed us to group together nine serovars for inclusion in the proposed species $L$. kirschneri. Serovar dania was a possible exception; unlike the other serovars, this serovar grew readily in the presence of 2,6 diaminopurine. The high level of homology between serovar dania and cynopteri DNAs (83\%) is highly suggestive that these two serovars are closely related, and variation in one phenotypic characteristic does not seem to be sufficient grounds for their separation at this juncture.

Description of Leptospira kirschneri sp. nov. L. kirschneri (kirsch'ner.i. N.L. gen. n. kirschneri, of Kirschner, in honor of Leopold Kirschner, a Dutch medical microbiologist who worked on leptospirosis research in Indonesia before coming to New Zealand to work at the Otago Medical School in Dunedin and whose pioneering work on leptospirosis helped focus attention on the human and animal health problem that existed at the time). L. kirschneri comprises nine serovars, serovars bulgarica, butembo, cynopteri, dania, grippotyphosa, kabura, kambale, ramisi, and tsaratsovo. With the exception of serovars grippotyphosa and cynopteri, the levels of DNA relatedness of these serovars have not been studied previously. L. kirschneri does not grow at $13^{\circ} \mathrm{C}$; growth is inhibited by 8 -azaguanine $(225 \mu \mathrm{g} / \mathrm{ml})$ and is usually inhibited by 2,6-diaminopurine. The type strain is a serovar cynopteri strain (3522C) that was first isolated from the short-headed fruit bat of Indonesia (Cynopterus sp.) by Collier and Mochtar (3).

\section{ACKNOWLEDGMENTS}

This work was carried out while P.R. was a Massey University Postdoctoral Scholarship recipient and was financed by a grant from the Veterinary Public Health Division of Communicable Diseases, World Health Organization, Geneva, Switzerland, and by the Massey University Research Fund.

\section{REFERENCES}

1. Brendle, J. J., M. Rogul, and A. D. Alexander. 1974. Deoxyribonucleic acid hybridization among selected leptospiral serotypes. Int. J. Syst. Bacteriol. 24:205-214.

2. Brenner, D. J., A. C. McWhorter, J. K. Leete-Knubon, and A. C. Steigerwalt. 1982. Escherichia vulneris: a new species of Enterobacteriaceae associated with human wounds. J. Clin. Microbiol. 15:1133-1140.

3. Collier, W. A., and A. Mochtar. 1939. Een serologisch afwijkende leptospira-stam uit der nier eener vleermuis. Gen. Tijdschr. Ned. Ind. 79:226.

4. Fitch, W. M., and E. Margoliash. 1967. Construction of phylogenetic trees. Science 155:279-284.

5. Haapala, D. K., M. Rogul, L. B. Evans, and A. D. Alexander. 1969. Deoxyribonucleic acid base composition and homology studies of Leptospira. J. Bacteriol. 98:421-428.

6. Jarvis, B. D. W., K. F. Scott, J. E. Hughes, M. Djordjevic, B. G. Rolfe, and J. Shine. 1983. Conservation of genetic information between different Rhizobium species. Can. J. Microbiol. 29: 200-209.

7. Johnson, J. L. 1984. Classification. III. Nucleic acids in classification, p. 8-11. In N. R. Krieg and J. G. Holt (ed.), Bergey's manual of systematic bacteriology, vol. 1. The Williams \& Wilkins Co., Baltimore.

8. Johnson, R. C., and S. Faine. 1984. Family II. Leptospiraceae, p. 62-67. In N. R. Krieg and J. G. Holt (ed.), Bergey's manual of systematic bacteriology, vol. 1. The Williams \& Wilkins Co., Baltimore.

9. Johnson, R. C., and V. G. Harris. 1967. Differentiation of pathogenic and saprophytic leptospires. I. Growth at low temperatures. J. Bacteriol. 94:27-31.

10. Johnson, R. C., and P. Rogers. 1964. Differentiation of pathogenic and saprophytic leptospires with 8 -azaquanine. J. Bacteriol. 88:1618-1623.

11. Kafatos, F. C., C. W. Jones, and A. Efstradiadis. 1979. Determination of nucleic acid sequence homologies and relative concentration by a dot hybridization procedure. Nucleic Acids Res. 7:1541-1552.

12. Kmety, E., and H. Dikken. 1988. Revised list of Leptospira serovars. International Committee on Systematic Bacteriology of IUMS, University Press, Groningen, The Netherlands.

13. Maniatis, T., E. F. Fritsch, and J. Sambrook. 1982. Molecular cloning: a laboratory manual. Cold Spring Harbor Laboratory, Cold Spring Harbor, N.Y.

14. Marshall, R. B., B. E. Wilton, and A. J. Robinson. 1981. Identification of leptospira serovars by restriction endonuclease analysis. J. Med. Microbiol. 14:164-166.

15. Seldin, L., and D. Dubnan. 1985. Deoxyribonucleic acid homology among Bacillus polymyxa, Bacillus macerans, Bacillus azotofixans, and other nitrogen-fixing Bacillus strains. Int. J. Syst. Bacteriol. 35:151-154.

16. Taylor, J. M., R. Illinensee, and J. Summers. 1976. Efficient transcription of RNA into DNA by avian sarcoma virus polymerase. Biochim. Biophys. Acta 442:324-330.

17. Yasuda, P. H., A. G. Steigerwalt, R. R. Sulzer, A. F. Kaufmann, F. Rogers, and K. J. Brenner. 1987. Deoxyribonucleic acid relatedness between serogroups and serovars in the family Leptospiraceae with proposals for seven new Leptospira species. Int. J. Syst. Bacteriol. 37:407-415. 